Бобан Ћурић

Универзитет у Београду

Филолошки факултет

boban.curic@fil.bg.ac.rs

https://doi.org/10.18485/ai_diskurs_pobede.2019.ch7

821.161.1.09-31 Савинков Б. В.

\title{
ИДЕЈНО УБИСТВО КАО ПОБЕДА ИЛИ ПОРАЗ АКТИВНЕ ЛИЧНОСТИ У РОМАНУ КОЬ БЛЕД Б. В. САВИНКОВА (В. РОПШИНА)
}

Идејно убиство као афирмација револуционарно-терористичке борбе и његова успешна реализација у сижеу романа Кою блеg (1909) као акта „победе“ сопствених идеолошких позиција дискредитују се етичким релативизовањем дозвољености убиства у свести главног јунака романа, Жоржа, његовим свођењем на чин етичког нихилизма снажне личности, „ослобођене“ свих норми које ограничавају-спутавају њено деловање. То доводи до спознаје апсолутног пораза и краха тако конципиране личности, која крај своје обесмишљене егзистенције види једино у самоубиству.

Кључне речи: Савинков (Ропшин), идејно убиство, етички нихилизам, руска књижевност.

Велику буру у руској књижевној јавности подигло је објављивање 1909. године ${ }^{1}$ романа Коњ блеg (Конь блеgныц̆), чији је аутор, скривен иза псеудонима В. Ропшин, разматрао етичку основу, односно етичку оправ-

1 Године 1909. објављено је у Русији цензурисано издање романа (Савинков 1992), док је пуна, нецензурисана верзија објављена у Ници 1913. године (Ропшин 1913). Сви цитати из романа дају се по овом, нецензурисаном издању романа, у нашем преводу. 
даност револуционарне борбе и идејног убиства. Догађај је попримио размере скандала када се открило да се иза псеудонима скрива Борис Викторович Савинков (1879-1925), познати револуционар, припадник партије есера (социјалиста-револуционара) и њеног терористичког огранка, Бојеве организације. За Савинкова је књижевно стваралаштво представљало одраз, односно реакцију на сопствену политичку делатност у време прве руске револуције 1905. године, израз разочарања њеним резултатима. Писање је код њега био начин да се промисли, преосмисли и сведе рачуне са сопственом револуционарном ангажованошћу кроз нову, уметничко-креативну форму, уздижући при том лично искуство до нивоа националне историозофске парадигме. Активни учесник руског идеолошког сукоба, заговорник терора (идејног убиства) као легитимног оруђа идејно-револуционарне борбе, са једне стране, и провокативни писац који дотиче нека непријатна, пре свега етичка питања граница личности, са друге стране, Савинков је био добар сликар апокалиптичког хаоса у коме се Русија на почетку XX века нашла.

Роман Кою блеg написан је у форми дневничких записа, које хронолошки води главни јунак романа, Жорж, вођа неименоване револуционарно-терористичке групе епохе прве руске револуције 1905. године, која има задатак да убије московског генерал-губернатора. ${ }^{2}$ Изразито субјективна исповедна форма забележака аутору даје могућност да представи сложени унутрашњи свет јунака, његов систем вредности и промене које у њему изазива сижејна акција, промене везане за етички проблем дозвољености убиства, што

2 У основи фабуле леже реални историјски догађаји 1904-1906. године. Види о томе: Чурич 2017. 
доприноси томе да динамичност унутрашњег плана нарације у потпуности одговара изразитој динамичности спољног сижејног плана. Тај спољни план обележен је двема сижејним линијама (убиство генерал-губерантора и љубавни конфликт), унутрашњи - постављањем етичког проблема дозвољености убиства.

Две паралелне сижејне линије међусобно се преплићу, обједињене личношћу главног јунака и истоветним моделом кулминативног развоја сижеа, истоветним моделом разрешења конфликта који им лежи у основи, и истоветним расплетом - убиством противника.

Без обзира на хронолошки континуитет, фабула не тече равномерно и праволинијски. Напротив, пуна је обрта, неочекиваних заплета и расплета, неуспеха једних сижејних решења и трагања за новим, неочекиваним прекидима и наглим заокретима сижејних токова. Достизање циља - победоносно реализовање јунакове замисли, убиства противника - у првој сижејној линији одлаже се неколико пута, а сваки „неуспех“ терористичке дружине може се посматрати као градациони степеник. Друга сижејна линија нешто је мирнија, временски краћа и стоји донекле у сенци прве (и по хронологији и по важности), али се и у њој готово од почетка назире и постепено нараста конфликт двојице мушкараца око вољене, са пресликавањем модела конфликта - заплета из прве сижејне линије. Место генерал-губернатора као јунаковог „личног“ непријатеља заузима муж вољене Јелене, што је на сижејном плану истакнуто њиховим честим довођењем у везу у јунаковој свести: „Мучи ме помисао на њега, на тог стаситог, плавокосог младића. [...] Чини ми се да је генерал-губернатор још увек жив“ (Ропшин 1913: 123). Разрешење двеју сижејних линија истоветним поступком, разрађеним у другом и трећем делу романа, на први поглед треба да 
представља јунакову победу, успех у постизању својих циљева. „Победа“, „успех“ су, међутим, само привидни и заправо представљају пораз личности, јер доводе до преосмишљавања ставова јунака и промене основног емотивног тона у њему.

У финалу романа сиже се са спољног преноси на унутрашњи план, конфликт јунака са светом преноси се на конфликт у самом јунаку, постављањем етичког проблема дозвољености убиства (конфликт који се назирао још током полемичких разговора Жоржа с идејним опонентом, Вањом, на тему љубави и убиства) поприма облике психолошке, душевне буре, што све резултира последњим чином јунака, најавом самоубиства душевно опустошене усамљене и празне јединке.

Централна тематска линија, питање дозвољености убиства, може се на сижејном плану градационо приказати на следећи начин: убиство из идеје - убиство као чин самовоље - самоубиство, дата кроз афирмацију библијске заповести „не убиј“, као основне етичко-филозофске поруке дела са свим, по личност и социјум страшним, деструктивним последицама њеног непоштовања.

Етичко-филозофски смисао књижевног првенца Савинкова открива се кроз новозаветни подтекст, исказан кроз два основна сегмента, јеванђељски и апокалиптички, и на фабуларном нивоу повезан с двојицом јунака, Жоржом и Вањом, припадницима револуционарно-терористичке групе. Кроз полемичку форму дијалога двојице јунака осмишљава се конфликт два приступа теми идејног убиства. И док је Жорж носилац идеје егоистичког нихилизма, етичке сведозвољености јаке личности, Вања носи погледе који би се најједноставније могли оценити као револуционарно хришћанство.

Вања - терориста у име Благе вести, носилац слова и духа Јеванђеља и лика Бога-љубави, Свемилостивог 
што прашта сваки грех, па и онај највећи - убиство; Жорж - окренут другом лику хришћанског бога, моћном Сведржитељу, гневном осветнику, онаквом какав је приказан у Откровењу Јовановом. Вања своју улогу у терору види као христолику жртву, преузимање греха убиства на себе зарад добробити других, Жорж, пак, себе посматра као извршитеља апокалиптичке освете и вишег суда. Жорж је главни јунак романа коме је у тексту све подређено; апокалиптички подтекст доминира, посебно када се онај други, Вањин јеванђељски, одбаци као „лажан“, неприхватљив, како за јунака (Жоржа), тако и за аутора, који исто сугерише и читаоцу. Зато је и наслов, Кою блеg, дат по слову и духу за роман најважније, апокалиптичке семантике.

Идеја победе у идеолошкој борби код Жоржа се асоцира са страшним судом и Божјом одмаздом, чији су извршиоци чланови Жоржове терористичке дружине: „Ко је подигао мач, од мача ће и да страда. Тако је написано у књизи живота. Ми ћемо је отворити и скинути печате: генерал-губернатор ће бити убијен“ (Ропшин 1913: 71). ${ }^{3}$ Уверен у победу и успех планиране акције убиства омраженог представника власти, Жорж узвикује: „Јер дан великог гнева ће доћи...// Ко ће моћи да му се одупре тога дана?“ (Ропшин 1913: 45; парафразирано Откр. 6, 17). После успешно изведене акције, када је већ извесно да је генерал-губернатор погинуо у бомбашком нападу, Жорж ће своју победу поздравити цитирањем још једне апокалиптичке сентенце: „Попут

3 У овој јунаковој сентенци парафразирано је Откр. 5-6: у визији св. Јована Богослова Агнец отвара књигу са седам печата, скидајући један по један печат; како их скида, појављују се апокалиптичка зла што кажњавају грешно човечанство, у облику четири коња са четири јахача, у хришћанској традицији познатих као четири јахача Апокалипсе 
светлог празника, свечане недеље звуче пророчанске речи: 'И изађе глас велики од престола, говорећи: Сврши се. Срећан сам: да, свршило се' (Ропшин 1913: 107; Откр. 16, 17). Проливена крв, смрт коју терористи око себе сеју, оличена је у страшној семантици четвртог коња Апокалипсе.

Осим апокалиптичког контекста бледог коња који сеје смрт, са главним јунаком Савинковљевог романа може се асоцирати још једна хришћанска митологема, веома важна за руску културну традицију. Са Георгијем Победоносцем, коњаником-ратником што убија змаја, Савинковљев роман од самог почетка повезује топос - Москва као место акције Жоржове терористичке дружине. Симболични заштитник Москве, свети Георгије, налази се и на московском, односно руском грбу. Светац-ратник, као прототип идеалног борца, близак је борбеном Жоржу, револуционару и терористи. Најважнија асоцијација, међутим, која главног јунака романа доводи у везу с хришћанским светим ратником јесте јунаково име, односно партијски надимак - Жорж, романизована варијанта имена Георгиј. Асоцијацију потврђује и конспиративни идентитет јунаков, лажни енглески пасош на име Џорџа О’Брајена (још једна варијанта имена Георгиј), којим се јунак служи за време свог првог боравка у Москви (Ропшин 1913: 5). Конфликт у обема сижејним линијама може се представити у кључу борбе ратника против непријатеља-змаја (оличеног у високом државном чиновнику, генерал-губернатору у првој, односно мужу вољене жене у другој сижејној линији). Ситуацију Георгија Победоносца у другој сижејној линији потврђује и јунаково уверење да ће убиством мужа „ослободити“ вољену, попут хришћанског свеца који убиством змаја спасава силенску принцезу. 
Готово с поносом, опијен снагом своје воље, пун мржње и жеље за осветом, Жорж истиче свој тријумф, власт над животом и смрћу других, али и нехотице указује на пустош у човековој души коју за собом оставља проливена крв: „Кажу још - треба волети човека. А ако у срцу нема љубави? Кажу, треба га поштовати. А ако нема поштовања? На граници сам живота и смрти. Шта ми значе речи о греху? За себе могу да кажем: 'и видех, и гле, коњ блед и јахач на њему коме је име Смрт'. Где ногом стане тај коњ, тамо вене трава, а где трава вене, тамо нема живота па, дакле, нема ни закона. Јер смрт није закон“ (Ропшин 1913: 57; Откр. 6,8). „Право“ на убиство (неважно чиме мотивисано) Жорж повезује с одсуством чврстих етичких норми: „Кад бих поштовао закон, не бих убијао, [...]. Али у чему је мој закон?“ (Ропшин 1913: 56). Право на убиство код јунака је само тест, коначна провера - доказ снаге сопствене воље, која проглашава апсолутну слободу и право на сведозвољеност која из те и такве слободе следи: „Сва моја воља састоји се у једном: у мојој жељи да убијем“ (Ропшин 1913: 50).

Да нема моралног закона пред којим би устукнула његова свемоћна воља, Жорж доказује новим убиством, овога пута из себичних, личних побуда, љубоморно се светећи мужу своје љубавнице Јелене, што скида сву илузију „исправности“ или могуће оправданости убиства. Уместо „вишег суда“, убиство постаје хир јунакове самовоље, сведозвољености, „смердјаковштине“ (Ропшин 1913: 31; в. такође и Ропшин 1913: 12; 13; 119), како се у роману назива. Мотив бледог коња, десакрализован и огољен у страшном тријумфу непотребне и бесмислене смрти, одјекује још дуго Жоржовом опустошеном душом: „Бледи коњ корачио је на траву, увела је трава. Људи су чули Реч - и ево, оскрнављена је Реч“ (Ропшин 1913: 136). 
У две основне сижејне линије романа, главни јунак доноси смрт другима, који су у његовој свести перцепирани као непријатељи - идеолошки или лични; готово сви јунаци из Жоржовог окружења, читава терористичка група, на овај или онај начин страдају насилном смрћу; терористичка активност дружине сеје смрт током романа и на многобројне случајне, „узгредне“ жртве. На крају, постепеним етичким дискредитовањем његових позиција, животни пут главног јунака завршава се уверењем да је самоубиство једини излаз из бесмисленог бивствовања: „Схватио сам: не желим више да живим. Досадиле су ми моје речи, моје мисли, моје жеље. Досадили су ми људи, њихови животи. Између њих и мене стоји зид. Постоје заветне границе. Моја граница је - крвави мач“ (Ропшин 1913: 143). Тријумф смрти тиме постаје потпун. Власт бледог коња у роману апсолутна је. Апокалиптички симбол сада се издиже изнад личних судбина јунака, преносећи своју семантику на читаву Русију, усковитлану у крвавом плесу смрти бесмисленог братоубилачког војевања.

Управо овде долази до важног семантичког преосмишљавања апокалиптичких мотива у Коюу блеgом - у Савинковљевом роману изостаје последња метаморфоза коју описује Откровење Јованово - коначна победа над злом и успостављање Царства Божијег, Новог Јерусалима, односно „раја на земљи“ или „бољег сутра“ као њихових револуционарних идеолошких еквивалената. Тако будућност Русије аутор Коюа блеgой, у духу наслова свог дела, види песимистички, у апологији бесмислене деструкције.

Основне идејне позиције главног јунака Жоржа одређујемо појмом егоистички нихилизам. ${ }^{4}$ Метафизич-

4 Види о томе подробније: Ћурић 2014. 
ка претпоставка егоистичког нихилизма јесте мисао коју је најјасније формулисао Достојевски, преко свог јунака Ивана Карамазова: ако нема Бога, онда је све дозвољено, јер ако Бога нема, онда нема ни било каквог вишег, надиндивидуалног обавезујућег закона: „ја“ сам на месту Бога, ја постављам законе према себи и мени је све дозвољено, јер нема ничег изван или изнад мене што би то оспорило.

Две су основне компоненте нихилистичке личности и обе се откривају у поступцима главног јунака романа: агресивни егоизам, изражен у апологији јаке, апсолутно слободне личности снажне, ничим неспутане воље, којом покорава презира достојно окружење, и - одрицање свих постојећих вредности и норми које стоје изван личности.

Као што то доликује духу нихилизма који у себи носи, Жоржова личност у роману покушава да се оствари кроз негацију: у духу идеолошке борбе он одриче власт, против које се терором бори; одриче, међутим, и идеолошку основу револуционарне борбе, такође одриче ауторитет партије, иако и сам у њеном оквиру делује. Одриче све религиозне и етичке норме, Христа и морал који почива на хришћанском систему вредности. Себе одређује као једини ауторитет и мерило свих ствари. Често понавља, у најразличитијим приликама: „Ја тако хоћу“ (Ропшин 1913: 23; 49; 50; 85; 129; 137); „Ја сам себи дозволио“ (Ропшин 1913: 101). Своју акцију у сижеу перцепира као победу, тријумф личности, врхунац њене слободне воље и слободног сврсисходног деловања. Реализација личности код Жоржа се поима као физичко и интелектуално наметање сопствене воље грубом силом и деспотизмом, као једином формом комуникације с другима.

У одрицању друштвено-социјалних, етичко-филозофских вредности Савинковљевог јунака руководи 
управо идеја о неограничености слободе сопствене воље, слободе неприкосновене личности, индивидуе изнад сваке идеологије, религије, политичке лојалности. Непријатељ се, сматра јунак, побеђује силом, у борби, а не речима, пропагандом и теоријама: „Верујем да сила ломи сламу, не верујем у речи. Да могу, побио бих све старешине и владаре“ (Ропшин 1913: 7-8). Себе перцепира изнад устаљених норми, изнад закона, попут ничеанског натчовека „с оне стране добра и зла“: „Шта је мој живот без борбе, без радосног сазнања да људски закони не важе за мене?“" (Ропшин 1913: 86). Релативизовањем етичких норми он одбацује основна начела која су до тада руководила револуционара - љубав, истину, правичност, разум.

Резултат, односно „последице“ успешне реализације сижејних акција јесу, заправо, јунаково преиспитивање сопствених становишта, што води ка дискредитовању његове апологије снажне личности чије су основе деловања агресивни егоизам и етички нихилизам. После другог убиства (мужа своје љубавнице Јелене) јунак се пита: „Ево, убио сам за себе. Прохтело ми се и убио сам. Ко је судија? Ко ће ме осудити? Ко ослободити кривице? [...] Зашто је за терор убити - добро, за отаџбину - неопходно, а за себе - недопустиво? Ко ће ми одговорити?“ (Ропшин 1913: 134).

На проливеној крви немогуће је осмишљавати било какву конструкцију. Попут јунака Злочина и казне, Раскољникова, и Жорж схвата да је убиством другог заправо убио себе: „Крв рађа крв и освета живи од освете. Нисам само њега убио..." (Ропшин 1913: 134).

У свеопштој негацији света око себе и етичких норми у себи, Жорж увиђа сав бесмисао даље егзистенције: „И људи овде траже смисао? И ја тражим некакав логички след? И Вања верује - Бог? И Хенрих је убеђен 
- слобода?.. Не, наравно, свет је једноставнији. Врти се досадна вртешка. Људи као муве хрле у ватру. У ватри страдају. А зар није све једно?“ (Ропшин 1913: 140). Или нешто касније: „Не волим више никога. Нећу и не умем да волим. Проклет нек је свет и пуст остао у једном трену: све је лаж и ништавност“ (Ропшин 1913: 143). Једини излаз из зачараног круга бесмисла јунак види у последњем самовољном чину слободне личности - самоубиству: „Схватио сам - не желим више да живим“ (Ропшин 1913: 143); „Отићи ћу из овог досадног циркуса“ (Ропшин 1913: 144); „Када се звезде упале и падне јесења ноћ рећи ћу своју последњу реч: мој револвер је са мном“ (Ропшин 1913: 144). Последња јунакова изјава заправо јесте пародирање Кантове сентенце о „звезданом небу изнад мене и моралном закону у мени“ (Кант 1979: 174). У складу са сопственим ставовима Жорж преосмишљава учење немачког филозофа о томе да је извор сваког моралног чина у вољи човека. Уместо категоричког императива, јунак инсистира на искључивости сопствене личности и њеног слободног деловања.

У исто време када настаје роман Кою блеg, настају и мемоарско-публицистичке Усйомене йерористие (Вос-

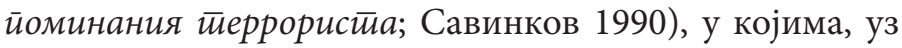
извесну дозу идеализације, аутор афирмише терор и политичко убиство као легитимно средство политичке борбе. Своје саборце, терористе, чланове Бојеве организације партије есера, Савинков приказује као титане идеје, храбре, пожртвоване, високо моралне и свесне велике одговорности, али и велике жртве за будућност, на коју су спремни да пођу. И сам активни учесник револуционарне борбе, Савинков на тај начин, парадоксално, у исто време и велича терор у мемоарско-публицистичком делу свога стваралаштва, и морално дискредитује идеју терора у књижевно-уметничком делу. 
Савинков у свом роману изражава једнозначно негативан став према нихилистичком становишту да снажна и самоуверена личност изузетног интелекта и воље јесте способна да преживи у свету без Бога, тиме што ће у себи наћи нове позитивне вредности. Савинков је овде близак руској књижевној традицији, која књижевне бунтовнике-нихилисте приказује као непријатељски настројене према животу, у постојаном конфликту с њим, што доводи до погубних последица по јунака (Печорин, Базаров, јунак из подземља, Раскољников, Кирилов, Ставрогин, Смердјаков, Иван Карамазов нпр.). Судбина Жоржа тако се поклапа и потврђује митологему краја руског моралног бунта: бунт-побуна против Бога и социјума јунака води ка неизбежном краху и суициду.

Апсурдни закључак који се намеће - највећа слобода личности доводи до обесмишљавања сврхе и циља њеног деловања. Питање граница људске слободе јесте етичко питање. Човек без слободе јесте део немуштог стада; са апсолутном слободом он постаје звер. Уместо безграничне слободе снажне личности која ради шта хоће, јер је сама себи етичка норма, Савинков схвата слободну личност у духу „образа Божијег“ у човеку и Христовог моралног закона, израженог кроз Божије заповести, од којих је свакако најважнија „не убиј“. Непоштовање овог закона неминовно води у пропаст аутодеструкције.

\section{Извори и литература}

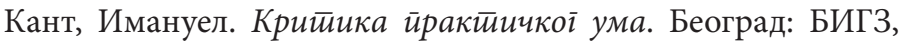
1979. Штампано.

Ропшин, Б. [Савинков, Борис]. Конь Блеgный. Ницца: Книгоиздательство М. А. Туманова, 1913. Штампано. 
Савинков, Борис. „Воспоминания террориста“. Избранное. Москва: Политиздат, 1990: 25-306. Штампано.

Савинков, Борис (Ропшин В.).„Коны бледный“. То, чеīo не бьло: Роман, повести, рассказы, очерки, стихотворения. Москва: Современник, 1992: 130-213. Штампано.

Ћурић, Бобан. „Коюь блеg Савинкова - Ропшина и поетика нихилизма“. Зборник Майиие срйске за славистиику 85 (2014): 53-68. Штампано.

Чурич, Бобан. „Конь блеgный Б. Савинкова (В. Ропшина) и идейное убийство: от события исторической реальности к событию в литературном произведении“. Slavica Tergestina 18 (2017/I); 164-185. Штампано.

Бобан Чурич

\section{ИДЕЙНОЕ УБИЙСТВО КАК ПОБЕДА ИЛИ ПОРАЖЕНИЕ ДЕЯТЕЛЬНОЙ ЛИЧНОСТИ В РОМАНЕ КОНЬ БЛЕДНЫЙ Б. В. САВИНКОВА} (В. РОПШИНА) РЕЗЮМЕ

Идейное убийство как афирмация революционно-террористической борьбы и его реализация в сюжете романа Конь блеgный (1909) Б. В. Савинкова (В. Ропшина, 1879-1925), воспринятые как «победа» собственных идеологических позиций, дискредитируются этической релятивизацией дозволенности убийства в сознании главного героя романа, Жоржа. Этический нигилизм, воспринятый как триумф воли и силы личности, «освобожденной» от каких-либо норм, ограничивающих ее деятельность, губит героя, приводит его к сознанию абсолютного краха сложившейся таким образом личности, которая единственный выход из своего окончательно обесмысленного существования находит в самоубийстве. 